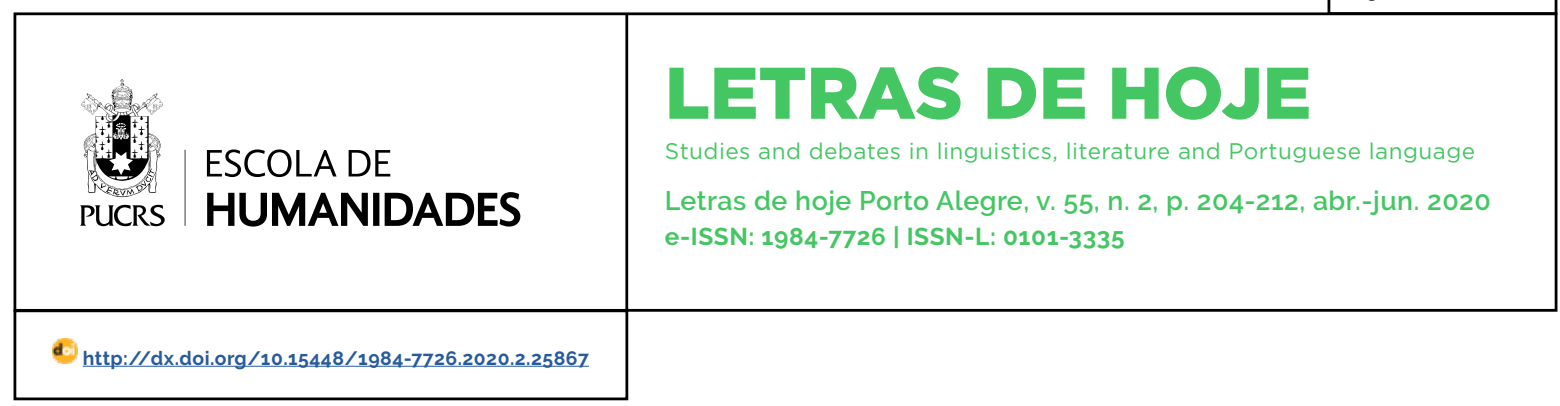

SEÇÃO: TEMÁTICA LIVRE

\title{
Relação icônica entre o protagonista e seu discurso em Quincas Borba ${ }^{1}$
}

\author{
Iconic relation between the character and his discourse in Quincas Borba
}

Relación icónica entre el protagonista y su discurso em Quincas Borba

\author{
Juracy Assmann \\ Saraiva ${ }^{2}$ \\ orcid.org/0000-0003-1783-2850 \\ juracy@feevale.br
}

\author{
Marinês Andrea Kunz ${ }^{2}$ \\ orcid.org/0000-0001-8964-1573 \\ marinesak@feevale.br
}

Recebido em: 24 nov. 2016. Aprovado em: 11 mar. 2020. Publicado em: 11 Set. 2020.

\begin{abstract}
Resumo: O artigo analisa a relação icônica que se estabelece entre a personagem Rubião, de Quincas Borba, e seu discurso, partindo do pressuposto de que esse procedimento expõe o processo crítico-reflexivo de Machado de Assis. A opção pela escrita como prática artesanal está manifestada na "Advertência", que abre Ressurreição, torna-se visivel no confronto entre as duas versões de Quincas Borba e ganha expressividade no tratamento conferido ao discurso do protagonista dessa narrativa. Ao explorar as possibilidades da linguagem, Machado confere aos signos verbais a natureza de gestos e neles imprime o poder de reproduzir especularmente o percurso de Rubião. Essa personagem progride de um estado de dispersão, manifestado por um discurso bivocal, até o da integridade na loucura, quando assume a univocidade discursiva. Ao evidenciar sentidos, os procedimentos narrativos compelem o leitor a buscar a intencionalidade do texto e dele migrar para o do contexto social, onde incide a denúncia do escritor. Palavras-chave: Machado de Assis. Quincas Borba. Personagem. Discurso. Iconicidade.
\end{abstract}

Abstract: The article analyses the iconic feature that is established between the character, Rubião, from Quincas Borba, and his discourse, based on the presupposition that this procedure exposes Machado de Assis' critical-reflective process. The selection of a writing style as a handcrafted practice is expressed in the "Advertência", that opens Ressurreição, and it becomes evident when the two versions of Quincas Borba are confronted to each other, leading the treatment disposed in the protagonist's discourse of the narrative to gain a surplus of expression. By exploring the possibilities of language, Machado gives the verbal signs the quality of natural gestures, and on them imprints the power to reproduce iconically the trajectory of Rubião. The character goes from a dispersive state, manifested by a bivocal discourse, to madness' integrity, when he takes over a discursive unicity. By making meaning evident, the discursive procedures impel the reader to look for the intentionality of the text, and through it, the reader may migrate to the social context where the denunciation of the author lays.

Keywords: Machado de Assis. Quincas Borba. Character. Discourse. Iconicity.

Resumen: El artículo analiza la relación icónica establecida entre el personaje Rubião, de Quincas Borba, y su discurso, basándose en el supuesto de que este procedimiento expone el proceso crítico reflexivo de Machado de Assis. La opción de escribir como práctica artesanal se muestra en la "Advertencia", que abre Ressurreição, se pone visible en la confrontación entre las dos versiones de Quincas Borba y gana expresividad en el tratamiento dado al discurso del protagonista de esta narrativa. Al explorar las posibilidades del lenguaje, Machado le da, a los signos verbales, la naturaleza de los gestos y en ellos impresiona el poder de reproducir especulativamente el camino de Rubião. Este personaje progresa de un estado de dispersión, manifestado por un discurso bivocal, al de integridad en la locura, cuando asume la univocidad discursiva. Al evidenciar los sentidos, los procedimientos narrativos llevan el lector a buscar la intencionalidad del texto y migrar de él al contexto social, donde se produce la denuncia del escritor. Palabras clave: Machado de Assis. Quincas Borba. Personaje. Discurso. Iconicidad. 


\section{Escrita e reflexão poética}

O enfoque sobre o processo composicional dos romances de Machado de Assis referenda as afirmações da crítica, que nele vê o artesão preocupado com o domínio técnico de seu métier. $^{2} \mathrm{O}$ envolvimento com o ofício leva o escritor a explorar convenções e procedimentos formais, convertendo sua práxis em reflexão sobre as potencialidades dos próprios meios e métodos, aspecto que pode ser identificado na concepção de Quincas Borba, quando são confrontadas suas duas versões e quando é analisada a configuração de seu protagonista.

O romance Quincas Borba é impresso, pela primeira vez, em seções, na revista A Estação, as quais ocupam, ainda que de forma descontinua, um periodo que se estende de 15 de junho de 1886 até 15 de setembro de 1891. Ao final desse mesmo mês, o romance recebe sua edição em livro, a qual revela ter sido a versão primeira submetida a inúmeros ajustes, na medida em que se dava a publicação dos diferentes capítulos sob forma de folhetim. Em ambas as versões, é apresentada a história de Rubião, o ingênuo professor de Minas Gerais que almeja brilhar na corte do Rio de Janeiro, apoiado na fortuna e na filosofia herdadas de Quincas Borba, mas que, ao se submeter a um processo de reificação, chega à miséria e à loucura. Entretanto, a semelhança do argumento não apaga as mudanças significativas que distinguem estrutural e discursivamente os dois textos e que assinalam a diligência de Machado em sua composição.

A opção pelo exercício da escrita como prática artesanal, que se torna visivel no confronto entre as duas versões de Quincas Borba e ganha expressividade no tratamento conferido ao protagonista, está expressa na "Advertência" de Ressurreição ${ }^{3}$, primeiro romance de Machado de Assis. Aí, o escritor se dirige à crítica para solicitar "intenção benévola, mas expressão franca e justa" e, rejeitando o valor de aplausos não fun- damentados no mérito, enfatiza a oportunidade de verdades, mesmo amargas, que atendam à "vontade de aprender". O escritor atribui ao tempo ou à maturidade a capacidade de dissipar a presunção dos indivíduos para dotá-los de uma indispensável dose de confiança e declara que a "reflexão" assume seu domínio com a passagem do tempo, condição também exigida para o "estudo". A seguir, distingue o grupo dos gênios, "a quem a natureza deu o poder quase inconsciente das supremas audácias", daqueles que, conhecendo os "modelos", "as leis do gosto e da arte" e a "extensão da responsabilidade" se sentem tolhidos, embora isso neles desperte uma "ambição refletida". Situando-se entre os últimos, afirma que as "tarefas literárias" são "nobres e consoladoras", "mas dificeis quando as perfaz a consciência" (ASSIS,1986a, p. 116).

A par de outras leituras possiveis, a advertência de Ressurreição assinala a preocupação de Machado de Assis com o ofício da escrita, em que não há lugar para a improvisação e o diletantismo. Ao se caracterizar como "operário", termo que remete à ideia do artífice que exerce uma ocupação manual bem como a do apóstolo que defende postulados e campanhas, o escritor prestigia o esforço contínuo e permanente, exigido em um processo de aprendizagem, valoriza o esmero técnico e enfatiza a importância do comportamento reflexivo e do distanciamento crítico em face das produções literárias pessoais e alheias. Estudo, trabalho e reflexão, desenvolvidos ao longo do tempo, podem, pois, ser apreendidos como o método que Machado de Assis aplica na concepção de suas obras e como principios mediante os quais justifica a natureza artesanal ou estética da literatura.

O método crítico-reflexivo de Machado expõe-se, como já referido, nas transformações que avultam na edição em livro de Quincas Borba, quando o processo narrativo é contraposto ao da versão em folhetim. A alteração da ordem de

\footnotetext{
2 Em crônica publicada em 1939, por ocasião do centenário de Machado de Assis, Mário de Andrade declara seu sentimento negativo em relação ao escritor, embora reconheça a perfeição técnica de suas obras, aspecto que já fora apontado por criticos anteriores e que merece atenção em estudos da atualidade. ANDRADE, Mário de. Machado de Assis. Aspectos da Literatura Brasileira. São Paulo: Martins, 1939 3 Para evitar a excessiva informação relativa às referências de Ressurreição e de Quincas Borba, as citações extraidas dessas obras serão indicadas apenas uma vez em cada parágrafo, quando todas se referirem à mesma página.
} 
exposição dos acontecimentos; a desarticulação da sequência evolutiva dos episódios; a maior dissolução do fluxo temporal; a supressão, condensação ou fusão de capítulos; o acréscimo de episódios são algumas das mudanças que o escritor imprime ao texto formatado em livro. Igualmente, há mudanças na configuração do narrador que, no romance em livro, se torna menos perceptivel do que no folhetim, apesar de suas constantes intervenções. O tratamento da focalização também é alterado, pois o narrador passa a reorientar sua onisciência para o ângulo subjetivo das personagens. O procedimento da caracterização das personagens, por sua vez, torna-se menos explícito, já que suas atitudes e pensamentos são apenas ocasionalmente declarados, enquanto o narrador busca integrar dados da espacialidade à ação desses agentes, reforçando sua conotação simbólica.

Na versão em livro, Machado de Assis opta por uma narração mais concisa, o que pode ser comprovado pela exclusão de episódios e pela caracterização do protagonista: enquanto, no folhetim, o interesse de Rubião pela herança de Quincas Borba fica explicito, no livro, essa faceta do caráter do protagonista é apenas sugerida. Procedimento semelhante ocorre na representação do sentimento amoroso de Rubião por Sofia, que é mais carnal e lúbrico no folhetim e mais idealizado e contido no livro, e essa contenção dos sentimentos é um dos fatores que ativa a empatia do leitor pelo amante menosprezado. Assim, em decorrência das sugestões e das significações implícitas na versão em livro, acentua-se, por um lado, o envolvimento afetivo do leitor e, por outro, sua atividade hermenêutica, pois ele deve preencher, na leitura, um maior número de vazios textuais para identificar, em Rubião, além da ingenuidade, sua falta de inocência.

Paralelamente, a análise da configuração do protagonista na versão definitiva de Quincas Borba comprova que Machado de Assis busca estabelecer uma correlação entre o protagonista e sua forma de representação e, portanto, instalar um elo analógico entre significante e significado. A caracterização de Rubião demonstra o procedi- mento, pois a configuração de seu discurso não apenas o revela enquanto agente que se institui por palavras, mas também o desenha, dando aos signos verbais a natureza de gestos e neles imprimindo o poder de reproduzir iconicamente a situação diegética. Dessa forma, os enunciados de Rubião colocam-no em cena, demonstram seus traços caracterológicos, estando as transformações por que passa representadas nas peculiaridades de seu discurso.

Consequentemente, a singularidade da caracterização de Rubião legitima o argumento de que Machado de Assis institui um vínculo especular entre o protagonista e sua representação, processo que ativa a dramaticidade do texto e contribui para manifestar sua intencionalidade. Com efeito, ao evidenciar o sentido, os procedimentos discursivos compelem o leitor a migrar do espaço do texto para o do contexto social, sobre o qual incide a denúncia do escritor.

\section{Especularização do protagonista}

A personagem romanesca se constitui em sua articulação com os demais elementos do universo ficticio a que pertence: ações, tempo, espaço, ângulos de percepção compõem fatores determinantes de uma constelação de significações de que ela emerge e que ela institui. Por meio da personagem, "a camada imaginária se adensa e se cristaliza" (CANDIDO, 1968, p. 21), todavia "as virtualidades semânticas e estéticas do texto narrativo dependem em larga medida do modo como nele se combinam, sobrepõem ou entrelaçam o discurso do narrador e os discursos das personagens" (REIS, 1988, p. 174). Essa afirmação ganha especial relevo quando se correlacionam a progressão da personagem e as marcas distintivas de seu discurso, para nelas identificar a convergência entre a significação e o modo de instituí-la por meio dos recursos da linguagem.

Três momentos distintos demarcam a evolução do percurso de Rubião e a iconicidade de seus enunciados em Quincas Borba: o primeiro abrange a expectativa do protagonista, ainda radicado na interiorana Barbacena, de ser beneficiado com a herança de Quincas Borba, a concretização desse 
desejo e a transferência para o Rio de Janeiro, onde conhece Sofia; o segundo, centra-se na tentativa malograda do protagonista de integrar-se à sociedade da corte e de conquistar Sofia, frustração que é compensada pela adesão ao sonho e ao desvario e secundada pela dilapidação da fortuna; o terceiro momento corresponde à rendição do protagonista, já empobrecido, às fantasias ditadas pela loucura e seu retorno à cidade de origem.

Machado de Assis assinala esses momentos conferindo-lhes enunciados discursivos que trazem em si as marcas do que devem representar. O primeiro momento pode ser exemplificado pelo capítulo inicial, que coloca Rubião em cena, no espaço em que as principais ações vão ocorrer:

Rubião fitava a enseada, - eram oito horas da manhã. Quem o visse, com os polegares metidos no cordão do chambre, à janela de uma grande casa de Botafogo, cuidaria que ele admirava aquele pedaço de água quieta; mas, em verdade, vos digo que pensava em outra cousa. Cotejava o passado com o presente. Que era, há um ano? Professor. Que é agora? Capitalista. Olha para si, para as chinelas (umas chinelas de Túnis, que the deu recente amigo, Cristiano Palha), para a casa, para o jardim, para a enseada, para os morros e para o céu; e tudo, desde as chinelas até o céu, tudo entra na mesma sensação de propriedade (ASSIS, 1986b, p. 643).

Sucinto e objetivo, esse incipit expressa o deslumbramento de Rubião, que, às primeiras horas da manhã, visualiza, a partir de seu palacete, a paisagem da enseada de Botafogo, enquanto relembra de seu passado humilde e o compara com o presente que é próspero, graças à herança que recebera do amigo Quincas Borba. Entretanto, o sentimento de euforia não desfaz a disforia, porque o protagonista se ressente da impossibilidade de anular a distância que se cava entre sua condição de proprietário e a de professor de Barbacena, que ele ainda traz dentro de si.

A ambivalência do sujeito, sua ruptura afetiva, é enfatizada no breve capítulo que sucede ao da abertura e em que Rubião se divide entre a alegria, pela posse da herança, e o remorso, por usufruir de bens que poderiam ter sido de sua irmã. O estado anímico do protagonista é iconizado pela orientação subjetiva de seu olhar, voltado ora para o espaço externo, ora para o espaço íntimo, e pelo enunciado verbal, também demarcado por essa mesma cisão:

\begin{abstract}
Que abismo que há entre o espirito e o coração! O espírito do ex-professor, vexado daquele pensamento, arrepiou caminho, buscou outro assunto, uma canoa que ai passando; o coração, porém, deixou-se estar a bater de alegria. Que lhe importa a canoa nem o canoeiro, que os olhos de Rubião acompanham, arregalados? Ele, coração, vai dizendo que, uma vez que a mana Piedade tinha de morrer, foi bom que não casasse; podia vir um filho ou uma filha... Bonita canoa! Antes assim! Como obedece bem aos remos do homem! O certo é que eles estão no céu! (ASSIS, 1986b, p. 643).
\end{abstract}

A frase inicial "Que abismo que há entre o espírito e o coração!" é um comentário do narrador que, restabelecendo os polos antitéticos passado e presente, terra e céu, sintetiza o estado interior de Rubião, dividido entre os laços afetivos e os interesses materiais. A constatação exclamativa dá lugar ao discurso narrativizado do narrador que, todavia, se deixa permeabilizar pelo ângulo avaliativo do "coração" do protagonista, cuja voz se manifesta através do discurso indireto livre: "Que lhe importa a canoa nem o canoeiro, que os olhos de Rubião acompanham, arregalados?" (ASSIS, 1986b, p. 643). A oposição entre espirito e coração é novamente demarcada pela frase subsequente, em que a dupla entonação narrador-personagem também se reúne em um todo sintático: "Ele, coração, vai dizendo que, uma vez que a mana Piedade tinha de morrer, foi bom que não casasse; podia vir um filho ou uma filha". Segue-se, então, a explicitação dos opostos, da dupla visualidade e da avaliação dual da personagem, configurada sob o diálogo interior: "Bonita canoa! Antes assim! Como obedece bem aos remos do homem! O certo é que eles estão no céu!" (ASSIS, 1986b, p. 643). Na representação, os enunciados não constituem réplicas de diálogo, mas a manifestação de diálogos paralelos, emitidos por uma única personagem, que se desdobra entre os impulsos do mundo interior e a sedução do espaço exterior, entre as sensações de alivio e de culpa, entre passado e presente, para explicitar sua dualidade.

Portanto, o início da narrativa centra-se na representação de um protagonista cindido, que 
revela inquietações, dúvidas, contradições, estado que é expresso mediante um discurso também dilacerado, em que a irrupção de enunciados próprios se soma aos alheios e em que a dualidade de perspectivas ou de pontos de vista caracteriza a manifestação discursiva.

O diálogo de Rubião consigo mesmo, com que se encerra o segundo capítulo, é, pois, característico dos pronunciamentos do protagonista, cuja cisão progride até alcançar a integridade subjetiva na loucura que, ao término do romance, coincide com a morte. Tanto a divisão quanto a unidade estão caracterizadas no discurso de Rubião, pois não "é a imagem do homem que é representada no gênero romanesco, mas a imagem de sua linguagem. Para presentificar-se, a personagem precisa tornar-se palavra, precisa construir a imagem através da emissão de seus lábios" (BAKHTIN, s/d, p. 156).

No segundo momento, o protagonista ilude-se quanto à possiblidade de conquistar Sofia e, pressionado pela falta de adaptação ao meio social, vivencia a experiência do duplo, sendo ora Rubião, ora um dos imperadores franceses, divisão que se transfere para o discurso, bipartido em vozes imisciveis, o qual se coaduna, portanto, com a diversidade dos sujeitos que habitam a interioridade de Rubião. Assim, incapaz de compor-se em integridade, Rubião é construido como ser multifacetado, cuja "consciência partia-se em duas, uma increpando a outra, a outra explicando-se, e ambas desorientadas" (ASSIS,1986b, p. 677), em que a ruptura interna, a não concordância consigo mesmo, gera um discurso também fendido.

Essa dualidade se exibe com maior evidência sempre que o protagonista se encontra diante de situações conflitivas, em que convergem problemas éticos e morais, como a do Capitulo XLV, em que relembra a declaração de amor que fizera a Sofia, no jantar, que ocorrera na casa dela: "Não posso, não devo, ia dizendo a si mesmo, não é bonito ir adiante. Também é verdade que, a rigor, não sou autor de nada; ela é que, desde muito, me anda desafiando. Pois que desafie agora! Sim, preciso resistir-lhe..." (ASSIS, 1986b, p. 677).
O duplo posicionamento, expresso nas ações de acusar e defender-se, desvela a interioridade de Rubião, que se divide entre a obediência às imposições morais, que condenam o adultério, e a transferência da culpa desse provável delito para Sofia, cuja atitude provocadora exigiria uma resposta da parte dele e diluiria, portanto, sua responsabilidade moral. Constata-se, porém, que as réplicas de acusação e defesa, opostas entre si e monoacentuais, não se fundem no plano do enunciado, senão no âmbito do indivíduo: elas se encadeiam como se duas subjetividades se confrontassem, embora a bipolaridade se concentre em um locutor único.

O narrador define essa indeterminação como caracteristica fundamental do protagonista, relatando uma situação do passado - "lá se iam longos anos" (ASSIS, 1986b, p. 678) - quando, andando pelas ruas da cidade, Rubião se deixa levar pelo acaso e se detém a olhar a execução de um negro que, na verdade, não queria ver. Entre o desejo de fugir e a necessidade de permanecer, ele se reveza, e as forças íntimas divergentes que nele coabitam estão inscritas na transposição de seus enunciados, que traduzem o antagonismo como vozes alternadas de um diálogo:

Foi aqui que o pé direito de Rubião descreveu
uma curva na direção exterior, obedecendo a
um sentimento de regresso; mas o esquerdo,
tomado de um sentimento contrário, deixou-se
estar; lutaram alguns instantes... Olhe o meu
cavalo! Veja, é um rico animal! Não seja mau!
Não seja medroso! (ASSIS, 1986b, p. 679).

Como o trecho em análise exemplifica, a concepção da personagem fundamenta-se em signos que mobilizam a percepção visual do leitor, visto que o narrador apela para a imagem plástica dos pés direito e esquerdo, com o intuito de figurativizar a dualidade. A concretude da representação é enfatizada pela reprodução do embate entre os cocheiros, que disputam o cliente Rubião entre si, e o embate entre o pé direito e o esquerdo, o que determina o espelhamento da divisão interior na enunciação discursiva do protagonista.

O nível diegético comprova que a dualidade de Rubião se constrói por sua relação com os outros, pois ele se olha "em todos os espelhos 
das consciências dos outros, conhece todas as possiveis refrações da sua imagem nessas consciências" (BAKHTIN, 1978, p. 144). Sobre si, sente constantemente o olhar do outro, que pode ser de repreensão, de zombaria ou de lisonja. Preocupado com a imagem que vê refletida nos olhos, nas palavras alheias, copia, imita os modelos próximos, deixando-se influenciar na maneira de ver, sentir, compreender e pensar o mundo que o cerca, visto que se submete à opinião alheia, estado de insegurança que o narrador expõe na duplicidade das vozes do enunciado: "Em que havia de dar o professor! Sentinela de cachorro! Rubião tinha medo da opinião pública" (ASSIS, 1986b, p. 651).

Essa preocupação com a opinião alheia revela-se, no discurso de Rubião, através da dualidade de perspectivas, e, no discurso do narrador, pela emergência das palavras do protagonista que, todavia, obedecem à injunção de posicionamentos alheios. Assim, ações e palavras mostram-se dilaceradas, pois entre o homem e sua expressão sublevam-se olhares alheios e palavras veladas, construindo-se um discurso contraditório e em contradição. Quando recebe a carta de Quincas Borba, em que este se apresenta como Santo Agostinho, Rubião pensa, inicialmente, que aquele perdera o juizo, logo após, supõe "que podia ser um gracejo do amigo". Mas, a segunda leitura confirma a primeira impressão: "Não havia dúvida; estava doudo. Pobre Quincas Borba! [...] Morria antes de morrer" (ASSIS, 1986b, p. 652). Entretanto, o texto do jornal confere-lhe nova possibilidade de apreciação, anulando a opinião pessoal:

Em seguida, atentando na notícia, viu que falava de um homem que tinha apreço, consideração, a quem se atribuia uma peleja filosófica. Nenhuma alusão à demência. Ao contrário, o final dizia que ele delirara a última hora, efeito da moléstia. Ainda bem! [...]. Pobre amigo! Estava são e morto. Sim, já não padecia nada (ASSIS, 1986b, p. 653).

Sob o discurso do narrador, transparece claramente o citado por Rubião, dividido entre o distanciamento crítico, provocado pela aparente falta de sentido da carta, e seu interesse, oriundo da esperança de um legado e pela sugestão da matéria do jornal: "Era um homem de muito saber..." (ASSIS, 1986b, p. 653). Em um momento, suas palavras afirmam o estado de demência do amigo e negam-no em outro, mostrando a contradição do protagonista e a sua incapacidade de estabelecer um sentido coerente e uniforme.

A análise dos enunciados do protagonista comprova, portanto, a iconicidade que se institui entre ele e seu discurso, que se alimenta da dispersão, até atingir a unicidade no plano da loucura. Inicialmente, o foco organizador é a visualização do entorno, é o olhar e a palavra do outro, o que significa, para Rubião, perder-se entre "os amigos de trânsito", com as constantes alterações de presenças e de individualidades, bem como jamais encontrar Sofia regida por uma conduta previsivel e única ${ }^{4}$. Em decorrência disso, Rubião transfere a alteridade alheia para si mesmo, desencontrando-se o homem e seu rosto, o homem e sua palavra.

A não concordância consigo mesmo, a perda da unidade "com a troca do meio e da fortuna" (ASSIS, 1986b, p. 712) conduzem à desestruturação mental, ao desdobramento da personalidade de Rubião, o que é assinalado, na narrativa, pela emergência de um interlocutor no âmago de seu discurso: "E por que não? Perguntou uma voz depois que o major saiu" (ASSIS, 1986b, p. 711). O questionamento decorre da sugestão que o major faz a Rubião, de que deveria casar-se; entretanto, como incisão linguística, o casamento é traço a dividir o homem em seu duplo, processo que a narrativa representa através da multiplicidade de vozes que se alternam no subconsciente de Rubião e das visões fantasmagóricas, desencadeadas pela ideia de um casamento que, segundo o protagonista, "podia ser o laço da unidade perdida" (ASSIS, 1986b, p. 712).

"Antes de cuidar da noiva, cuidou do casamento" (ASSIS, 1986b, p. 712), afirma o narrador,

\footnotetext{
4 O narrador assim registra o sentimento de dispersão do protagonista: "Rubião sentia-se disperso; os próprios amigos de trânsito, que ele amava tanto, que o cortejavam tanto, davam-lhe à vida um aspecto de viagem, em que a lingua mudasse com as cidades, ora espanhol, ora turco. Sofia contribuía para esse estado; era tão diversa de si mesma, ora isto, ora aquilo, que os dias iam passando sem acordo fixo, nem desengano perpétuo" (ASSIS, 1986b, p. 712)
} 
valendo-se de sua visão e onisciência soberanas para narrar o episódio. Entretanto, a ambivalência transfere-se também ao ato de narrar, e o discurso narrativizado passa a suporte retórico para a projeção do olhar e da palavra de Rubião. São dele os olhos que veem, é sua a mente a vagar entre sonhos de magnificência, é sua a emoção e suas são as palavras. Impulsionadas pela força imaginativa do devaneio, as visões de Rubião concebem a personificação do poder ("o internúncio", "o ministro da Rússia", "generais", "diplomatas", "as grandes damas") e de seus emblemas ("carruagens", "sapatinhos de cetim", "meias roxas"), mas também a personificação dos objetos e a reificação dos individuos, que, designados metonimicamente, se nivelam aos objetos que criam o cenário da pompa aristocrática:

Os lustres de cristal e ouro alumiando os mais belos colos da cidade, casacas direitas, outras curvas ouvindo os leques que se abriam e fechavam, dragonas e diademas, a orquestra dando sinal para uma valsa. Então os braços negros, em ângulo iam buscar os braços nus, enluvados até o cotovelo, e os pares saíam girando pela sala, cinco, sete, doze, vinte pares (ASSIS, 1986b, p. 713).

O traço aspectual dos enunciados acima transpostos, ou seja, a duração que os caracteriza, denota a intensidade da emoção do protagonista, que, em seu estado passional, apreende os objetos como um prolongamento de si mesmo. Em decorrência disso, a enunciação provém do ângulo do sujeito que percebe e sente e cujas marcas estão assinaladas na seleção ditada pelo olhar e no prosaísmo da linguagem, embora a presença do narrador seja ainda perceptível. Assim, o ato de narrar é duplamente possuido pelo narrador e pela personagem, estendendo-se a desestruturação dessa para o discurso que deve institui-la.

Incapaz de anular as imagens sedutoras e as palavras veladas e de abstrair-se das proposições de "uma sociedade fidalga e régia" (ASSIS, 1986b, p. 712) e sentindo, ao mesmo tempo, a "nostalgia do farrapo, da vida escassa, acalcanhada e sem vexame" (ASSIS, 1986b, p. 717); impotente em conduzir-se diante de uma realidade sempre movente e sempre outra, Rubião refugia-se em nova iden- tidade. Para concebê-la, adota uma máscara que tem um ícone esculpido em mármore por modelo: "Quero restituir a cara ao tipo anterior; é aquele" (ASSIS, 1986b, p. 766), declara o protagonista ao barbeiro, apontando para o busto de Napoleão III.

Os traços do imperador dos franceses, impressos no rosto e referendados em palavras e gestos, são a maneira que o protagonista encontra para responder aos apelos não satisfeitos de opulência, para superar frustrações e concretizar sonhos irrealizáveis. Contudo, o aspecto soberano da máscara não esconde a origem parodística, em que a semelhança expõe também a diferença tanto entre a cópia e o modelo, quanto entre este e a ideia que intenta representar: imitação da imitação, Rubião não é Napoleão III, que não é Napoleão, mas um arremedo de suas glórias, expresso por meio de luxo e falso esplendor. Assim, em sua progressão, a narrativa registra, sob o ângulo visual do narrador e de personagens, a diferença entre Rubião e seu modelo, assinalando a deterioração física e psíquica daquele. Com efeito, na medida em que constrói a semelhança de sua imagem com aquela ditada pelo desvario, o protagonista estabelece o mimetismo entre o desejo e sua representação pela linguagem.

Alcançado o terceiro estágio do percurso, a imersão total na loucura confere integridade ao protagonista, que já não é Rubião, mas apenas Napoleão III, de modo que seu discurso também passa a ser marcado pela unicidade, traço que possibilita a ele anular a distância entre a ilusão e o real. Outro o rosto, outro o discurso do homem. Rubião-imperador já não é submisso e é ele quem se dirige ou responde a subordinados. As palavras do outro, antes apreendidas em seu caráter polêmico, excluem-se do limite de sua consciência, porque já não há, para o protagonista, um discurso alheio a interferir na enunciação. Agora é o discurso próprio que se biparte, para compor-se em duas vozes, não apenas duas perspectivas linguísticas radicadas no mesmo ser, mas dois indivíduos radicados em um. Com efeito, se no estado de lucidez irrompiam os enunciados alheios sob suas palavras, na alienação, porque os ruídos exteriores não mais o 
atingem, um dos discursos do protagonista é discurso alheio. Dessa forma, é o "imperador" que fala, calcando seu discurso sobre os sonhos de Rubião, como na passagem em que ele se dirige a Sofia, tratando-a como se fosse sua amante:

Não te espantes, continuou ele; não nos vamos separar; não, não te falo de separação. Não me digas que morrerias; sei que havias de chorar muitas lágrimas. Eu não, que não vim ao mundo para chorar, mas nem por isso a minha dor seria menor; ao contrário, as dores guardadas no coração doem mais que as outras. (ASSIS, 1986b, p. 771).

Percebe-se claramente que o discurso se expressa como um diálogo velado. As palavras do segundo interlocutor estão ausentes, intuindo-se, porém, seu sentido geral como se tivessem sido explicitadas. Embora só o protagonista fale, sua enunciação se apresenta como um diálogo sumamente tenso, "pois cada uma das palavras presentes responde e reage com todas as suas fibras ao interlocutor invisivel, sugerindo fora de si, além de seus limites, a palavra não pronunciada do outro" (BAKHTIN, 1981, p. 171).

O registro dessa enunciação dual revela que Rubião-imperador dialoga com Sofia não aquela que - acompanha no coupé, mas a Sofia cuja realidade ele compõe através de seus desejos. Consequentemente, o diálogo perfaz-se entre Rubião e seu duplo, ou melhor, entre os sonhos concretizados de Rubião: o sonho de amor e o sonho de magnificência. Assim, embora Sofia emudeça, as ilusões acalentadas pelo desejo falam em seu lugar.

Por sua vez, a menção à sociedade fidalga, à realeza, aos combates e às vitórias, feitas por Rubião, recobre situações alheias ou fictícias, depreendidas da leitura de romances ou jornais, mas que se inscrevem nas palavras do protagonista como se resultassem de experiências pessoais e verídicas. Portanto, é a consciência perdida em devaneios que permite o diálogo com as idealizações da consciência anterior: ambas são equipolentes, equidistantes e imisciveis, fazendo do discurso um discurso a duas vozes.

O povoamento de vozes no discurso manifesta, no plano formal da enunciação, a perda da integridade psiquica e a vivência de simulacros que compensam a incapacidade do protagonista de apreender a significação, não menos fantasmática, do real. Por isso, se já não é o capitalista, tampouco o mestre da província, mas o imperador Napoleão III, a linguagem de Rubião é "também diversa, rotunda e copiosa e assim os pensamentos, alguns extraordinários". Negando o real, isto é, ignorando os apelos da realidade circundante. Rubião consegue alcançar o "conhecimento do inextricável" (ASSIS, 1986b, p. 775), identificar-se consigo mesmo e munir-se de todas as qualidades e poderes, de todos os sentimentos e desejos de que antes se sentia privado.

O novo discurso corresponde, pois, ao novo rosto ou ao disfarce que exerce o fetichismo mágico de identificar Rubião à "imagem ideal, reflexo em seu desejo da forma que desenha para ele o olhar de um outro, que o julga e seduz" (LEMAIRE, 1979, p. 33). Revestir-se de Napoleão III é um modo de prevalecer, de afirmar-se como único diante de um duplo olhar: o próprio e o alheio, no qual, enquanto sujeito, vê sua imagem refratada. Como Rubião, o protagonista visualizara o menosprezo no olhar do outro; como Napoleão, ele degrada o outro com seu olhar. Todavia, a coexistência da dupla identidade conduz, progressivamente, à negação total da primeira pela afirmação da segunda, alterando-se, em função disso, o modo de enunciação.

Assim, se os enunciados dialógicos comprovam a ruptura entre o protagonista e o real ou a divisão de sua identidade, a imersão no exilio da loucura restitui-lhe a integridade perdida e a unicidade discursiva. Justifica-se, portanto, a afirmação do narrador segundo a qual Rubião "não morreu súdito nem vencido", pois, ao coroar-se no momento da agonia, ele confirma sua adesão plena ao delírio, onde as imagens visuais e as palavras que as reproduzem elidem a lacuna entre o simbolo e sua representação para configurarem a própria coisa simbolizada (CÂMARA JR., 1962). A visão e a crença do protagonista, endossadas pelo narrador, transformam o "nada" ou a inanidade de uma ilusão na concretude do objeto: uma coroa "pesada de ouro, rútila de diamantes e outras pedras preciosas" (ASSIS, 1986b, p. 806). 
Inserida no âmbito dos sentidos que a narrativa sugere, a situação deixa de restringir-se aos dados da referencialidade textual, em que um louco, de mãos vazias, cinge uma coroa inexistente, para manifestar a intencionalidade do autor. A relação de similitude entre o "nada" e a coroa concentra a denúncia de Machado de Assis diante da ruptura que se instala entre o real e seus signos, entre as imagens e sua significação. Para atender a esse fim, Machado cria um discurso ou um processo de enunciação que reproduz especularmente o próprio enunciado e em que o universo diegético se povoa de imagens visuais para, através delas, compor uma reflexão crítica sobre o fascínio da aparência e o menosprezo pela substancialidade. Assim sendo, o gesto de Rubião nada mais é do que o denominador comum de uma imagem coletiva, uma vez que os indivíduos se apegam ao visivele se refugiam por detrás de máscaras em que forjam seu desejo e as expectativas da malha social.

Espectador, analista e crítico da condição humana, Machado de Assis transpõe para o romance Quincas Borba, por meio da representação de Rubião, a imagem, visualmente instituída, do homem desestruturado, dividido e, finalmente, integrado a si mesmo pela negação da realidade, imagem que se duplica pelo mimetismo da linguagem. Paralelamente, o escritor transporta o olhar do leitor para seu contexto, impelindo-o a identificar, na narrativa, a denúncia da crença em uma realidade que se forja sobre o aparente e o ilusório. Esse processo enriquece o tecido do texto, pois enquanto, por um lado, presentifica o contexto humano para desnudá-lo, por outro, evidencia as possibilidades significativas da própria linguagem e o trabalho artesanal que lhe dá forma.

Portanto, a articulação entre a trajetória do protagonista de Quincas Borba e seu discurso, a qual estabelece um processo de espelhamento entre ambos, transcendendo os limites do texto para mimetizar o contexto social, bem como o trabalho de reelaboração desse romance, em que a segunda versão se distingue substancialmente da primeira, salientam o trabalho meticuloso que Machado realiza em seus textos. Comportando-se como um artífice que valoriza o esmero e a técnica, resultantes de um exercício de experi- mentação e de aprendizagem, ele confirma a importância que confere ao oficio do escritor e à literatura como manifestação estética. Por sua vez, a opção pelo estudo, trabalho e reflexão garantem à sua obra o reconhecimento da crítica e a inclusão do nome de Machado de Assis entre os mais importantes romancistas do século XIX.

\section{Referências}

ASSIS, Machado de. Ressurreição. In: ASSIS, Machado de; COUTINHO, Afrânio (org.). Obra completa. Rio de Janeiro: Nova Aguilar, 1986a. v. 1, p. 641-806.

ASSIS, Machado de. Quincas Borba. In: ASSIS, Machado de; COUTINHO, Afrânio (org.). Obra completa. Rio de Janeiro: Nova Aguilar, 1986b. v. 1, p. 115-195.

BAKHTIN, Mikhail. Esthétique et théorie du roman. Paris: Gallimard, 1978.

BAKHTIN, Mikhail. Problemas da poética de Dostoiéwski. Rio de Janeiro: Forense Universitária, 1981.

CÂMARA JÚNIOR, João Mattoso. A coroa de Rubião. In: CÂMARA JÚNIOR, João Mattoso. Ensaios Machadianos. Rio de Janeiro: Acadêmica, 1962. p. 53-61.

CANDIDO, Antonio et al. A personagem de ficção. São Paulo: Perspectiva, 1968.

LEMAIRE, Anika. Jacques Lacan: uma introdução. Rio de Janeiro: Campus, 1979.

REIS, Carlos. Dicionário de teoria da narrativa. São Paulo: Ática, 1988.

\section{Juracy Assmann Saraiva:}

Mestrado em Letras na Universidade Federal do Rio Grande do Sul, o doutorado em Teoria da Literatura na Pontificia Universidade Católica do Rio Grande do Sul e o pós-doutorado em Teoria da Literatura na Universidade Estadual de Campinas. É professora e pesquisadora da Universidade Feevale, Coordenadora do Mestrado Profissional em Letras e bolsista de produtividade do CNPq.

\section{Marinês Andrea Kunz:}

Mestrado em Comunicação na Universidade do Vale do Rio dos Sinos e o doutorado em Teoria da Literatura na Pontifícia Universidade Católica do Rio Grande do Sul. É professora e pesquisadora da Universidade Feevale, atuando em cursos de graduação e de pós-graduação.

\section{Endereço para correspondência}

Juracy Assmann Saraiva

RS-239, 2755

Vila Nova, 93525-075

Novo Hamburgo, RS, Brasil 